\title{
Opinions of pre-school pre-service teachers concerning tales: The case of TRNC
}

\author{
Selma Korkmaz ${ }^{1, *}$ \\ ${ }^{1}$ Near East University, Ataturk Faculty of Education, Department of Turkish Language Teaching, \\ 99138 Nicosia, North Cyprus
}

\begin{abstract}
Tales have an important place in the education lives of children. For this reason, attention should be paid to the qualifications of tales read to the children in pre-school period. Pre-school teachers have important roles to play in this regard. The purpose of this study is to obtain the opinions of pre-school pre-service teachers who will serve as preschool teachers in the future concerning tales and explore whether they have adequate knowledge and awareness. For this purpose, our study group consists of 60 pre-service teachers studying at $4^{\text {th }}$ grade of Near East University Atatürk Education Faculty Preschool Teaching Department. Interview forms were used in the collection of data. Frequency, percentage and content analysis were used in the analysis of data. Based on the findings obtained, it is determined that pre-service teachers have a certain accumulation of knowledge concerning tales; however, it became evident that this knowledge is inadequate and that they are under the impact of foreign culture, and that they have little knowledge about Turkish tales although they are senior students. At the same time, pre-service teachers declare that when they become teachers they will teach some tales which they claim that have negative effects on children, which is an indication that they do not have conscious.
\end{abstract}

\section{Introduction}

Tales are defined as "a literary genre generally created by people, based on imagination, living in verbal tradition, and mostly citing the supernatural events that happen to people, animals, witches, goblins, giants, fairies etc." [1]. They are also defined as folk stories which mostly tell the narratives of extraordinary characters and adventures, and are based on imaginary subjects, which spread abroad from one person to another [2].

Tales have an important place in the culture, education and social life of a nation. Tales include several features concerning the ethical structure of a society, its traditions and customs, national elements, religious beliefs and national languages of a society and make considerable contribution in the members of a society in learning its cultural values. Tales also make contribution to the development of children in the field of education and have an important place in the acquisition of four basic language skills, namely reading, speaking writing and listening and teaching the richnesses of the native language. Individuals learn

* Corresponding author: selma.korkmaz@neu.edu.tr 
how they should behave in social life based on human relations, friendship emotion, love for mother and father, keeping secrets, sense of sharing and amity in the tales.

Considering that tales are valuable in terms of preparing the child for life and giving $\mathrm{him} /$ her a favorable place in the society, preschool teachers have huge roles to play. Preschool teachers have to pay attention to the characteristics of the tales that children read. The purpose of this study is to obtain the opinions of preschool pre-service teachers who will work as preschool teachers in the future concerning tales and explore whether they have awareness about tales.

\section{Method}

\subsection{Study Group}

Our study group consists of 60 senior pre-service teachers studying at preschool teaching department of Atatürk Education Faculty of Near East University. The reason for preferring senior students at preschool teaching department is that they are believed to have wide knowledge accumulation on several topics concerning their profession and the necessary experience as they completed their internship program.

\subsection{Collection of Data}

Interview form was used in data collection. This interview form consists of the following 7 questions:

1. Which tales are you planning to read to your students when you become a teacher? Which criteria will you pay attention in choosing the tales that you will read?

2. In your opinion, which tales affect the children negatively? Why?

3. In your opinion, which elements affect the children negatively in tales?

4. Do you think that having elements contrary to our cultural values in the tales that you will read is inconvenient? Why?

5. In your opinion, what kind of an impact do the children have on the development of children?

6. Do you think that tales entail children to extreme imaginary worlds? Why?

7. What are your positive and negative opinions concerning the elements that belong to our culture in the tales?

\subsection{Analysis and interpretation of data}

Frequency, percentage and content analysis were used in the analysis of data. The data obtained from interview form were evaluated by creating various codes and themes and tabulation.

\section{Findings and Comments}

It is seen that pre-service teachers gave more than one answers to some questions in the interview form. For this reason all answers were included in the evaluation. 


\subsection{Findings concerning the tales that pre-service teachers are considering to read to their students when they become teachers and the criteria that they will consider in choosing these tales}

Table 1. Frequency and percentage distribution of pre-service teachers concerning the tales that they consider reading to their students when they become teachers

\begin{tabular}{lcc}
\hline \multicolumn{1}{c}{ Title of the tale } & f & \% \\
\hline Snow-White and The Seven Dwarves & 15 & 25,00 \\
Little Red Riding Hood & 10 & 16,66 \\
Cinderella & 9 & 15,00 \\
Cicada and The Ant & 7 & 11,66 \\
Rapunzel & 5 & 8,33 \\
Pinocchio & 4 & 6,66 \\
Dede Korkut Tales & 4 & 6,66 \\
Sleeping Beauty & 3 & 5,00 \\
Frog and The Rabbit & 1 & 1,66 \\
Snow Queen & 1 & 1,66 \\
Little Mermaid & 1 & 1,66 \\
The Lion King & 1 & 1,66 \\
The Little Match Girl & 1 & 1,66 \\
Heidi & 1 & 1,66 \\
Liar Shepherd & 1 & 1,66 \\
Ali Baba and The Forty Thieves & 1 & 1,66 \\
Little Black Fish & 1 & 1,66 \\
Fairy Tale & 1 & 1,66 \\
La Fontaine Tales & 1 & 1,66 \\
Nasrettin Hodja Tales & 1 & 1,66 \\
Lion and The Mosquito & 1 & 1,66 \\
The Ugly Duckling & 1 & 1,66 \\
Alice in Wonderland & 1 & 1,66 \\
Crow and The Fox & 1 & 1,66 \\
\hline
\end{tabular}

According to table 1, 25\% of pre-service teachers told that they would read Snow-White and The Seven Dwarves, $16.66 \%$ told that they would read the Little Red Riding Hood, $15 \%$ told that they would read Cinderella, $11.66 \%$ stated that they would read Cicada and The Ant, 8.33\% told that they would read Rapunzel, $6.66 \%$ told that they would read Pinocchio, 6.66\% told that they would read Dede Korkut, 5\% told that they would read Sleeping Beauty and $26.66 \%$ told that they would read other tales to in the table to their students when they become teachers. Considering these tales, it is seen that teachers mostly consider foreign tales but do not even mention Turkish tales such as Keloğlan.

Table 2. Frequency and percentage distribution of pre-service teachers concerning the criteria that they will consider in choosing the tales that they are planning to read to their students when they become teachers

\begin{tabular}{lcc}
\hline \multicolumn{1}{c}{ Theme } & f & $\mathbf{\%}$ \\
\hline Being educative and didactic & 29 & 48,33 \\
Being suitable for the age group of the children & 19 & 31,66 \\
Strengthening the imagination & 9 & 15,00 \\
Including cultural elements & 8 & 13,33 \\
Relating to the daily life & 7 & 11,66 \\
Making considerable use of pictures & 6 & 10,00 \\
Being written with a clear and understandable language & 6 & 10,00 \\
Having and entertaining dimension & 5 & 8,33 \\
Making contribution to the development of the child & 4 & 6,66 \\
Tale cover being convenient to the content & 1 & 1,66 \\
\hline
\end{tabular}


The criteria that pre-service teachers would consider in choosing tales are given in Table 2. Accordingly, $48.33 \%$ of pre-service teachers stated that they chose the tales considering the criterion of being educative and didactic, $31.66 \%$ of pre-service teachers stated that they chose the tales considering the criterion of being suitable for the age group of children, $15 \%$ of pre-service teachers stated that they chose the tales considering the criterion of strengthening the imagination, $13.33 \%$ of pre-service teachers stated that they chose the tales considering the criterion of including cultural elements, $11.66 \%$ of preservice teachers stated that they chose the tales considering the criterion of relating to daily life, $10 \%$ of pre-service teachers stated that they chose the tales considering the criterion of making considerable use of pictures, another $10 \%$ of pre-service teachers stated that they chose the tales considering the criterion of being written with a clear and understandable language, $8.33 \%$ of pre-service teachers stated that they chose the tales considering the criterion of having an entertaining dimension, $6.66 \%$ of pre-service teachers stated that they chose the tales considering the criterion of making contribution to the development of the child and $1.66 \%$ of pre-service teachers stated that they chose the tales considering the criterion of tale cover being convenient to the content. The most important reason of teaching tales from very early ages is to teach the child cultural elements, however, it has been found out that only $13.33 \%$ of pre-service teachers have such awareness.

\subsection{Findings concerning which tales have negative impact on children and why these tales affect children negatively}

Table 3. Frequency and percentage distribution of pre-service teachers concerning which tales affect children negatively

\begin{tabular}{lcc}
\hline \multicolumn{1}{c}{ Title of the tale } & f & \% \\
\hline Snow-White and The Seven Dwarves & 9 & 15,00 \\
Rapunzel & 8 & 13,33 \\
Cinderella & 8 & 13,33 \\
Little Red Riding Hood & 7 & 11,66 \\
Smurfs & 5 & 8,33 \\
Spider-Man & 5 & 8,33 \\
Batman & 5 & 8,33 \\
Pinocchio & 5 & 8,33 \\
Lucky Luke & 4 & 6,66 \\
Dede Korkut Tales & 3 & 5,00 \\
Ali Baba and The Forty Thieves & 3 & 5,00 \\
Hansel and Gretel & 2 & 3,33 \\
Heidi & 1 & 1,66 \\
Pollyanna & 1 & 1,66 \\
The Phoenix Tale & 1 & 1,66 \\
Beauty and The Beast & 1 & 1,66 \\
Cicada and The Ant & 1 & 1,66 \\
Puss in Boots & 1 & 1,66 \\
Arabian Nights Tales & 1 & 1,66 \\
Tin Soldier & 1 & 1,66 \\
The Ugly Duckling & 1 & 1,66 \\
\hline A can be seen in table 3, & &
\end{tabular}

A can be seen in table 3, 15\% of pre-service teachers indicated Snow-White and The Seven Dwarves, $13.33 \%$ indicated Rapunzel, $13.33 \%$ indicated Cinderella, $11.66 \%$ indicated Little Red Riding Hood, 8.33\% indicated Smurfs, 8.33\% indicated Spider-Man, $8.33 \%$ indicated Batman, 8.33\% indicated Pinocchio, 6.66\% indicated Lucky Luke, 5\% indicated Dede Korkut, 5\% indicated Ali Baba and The Forty Thieves, 3.33\% indicated Hansel and Gretel, and 15\% indicated Heidi, Pollyanna, the Phoenix Tale, Beauty and The Beast, Cicada and The Ant, Puss in Boots, Arabian Nights, Tin Soldier and The Ugly 
Duckling as the tales which affect children negatively. However, it is seen that pre-service teachers are under the effect of some cartoons and thought that such cartoons as SpiderMan, Batman and Lucky Luke are tales.

Table 4. Frequency and percentage distribution of pre-service teachers concerning the reasons of tales which affect children negatively

\begin{tabular}{lcc}
\hline \multicolumn{1}{c}{ Theme } & f & $\mathbf{\%}$ \\
\hline Including violence and horror elements & 32 & 53,33 \\
Being unrelated with reality & 19 & 31,66 \\
Being not convenient for cultural values & 11 & 18,33 \\
\hline
\end{tabular}

According to table $4,53.33 \%$ of pre-service teachers think that tales which include violence and horror elements affect children negatively, $31.66 \%$ pre-service teachers think that tales which are unrelated to reality affect children negatively, and $18.33 \%$ of preservice teachers think that tales which are not convenient for cultural values affect children negatively.

\subsection{Findings on the elements in tales which affect children negatively}

Table 5. Frequency and percentage distribution of pre-service teachers concerning the elements which affect children negatively in tales

\begin{tabular}{lcc}
\hline \multicolumn{1}{c}{ Theme } & f & $\mathbf{\%}$ \\
\hline Violence-war-fighting-guns & 34 & 56,66 \\
Dragons-monsters & 20 & 33,33 \\
Evil behaviors-evil & 20 & 33,33 \\
Witches & 16 & 26,66 \\
Magic-spell & 16 & 26,66 \\
Goblins & 13 & 21,66 \\
Fairies & 11 & 18,33 \\
Wolves & 11 & 18,33 \\
Strict rules & 10 & 16,66 \\
Theft & 7 & 11,66 \\
Giants & 5 & 8,33 \\
Negative wording & 1 & 1,66 \\
\hline
\end{tabular}

An examination of Table 5 shows that $56.66 \%$ of pre-service teachers think that such elements as violence, war, fighting and guns in tales affect children negatively, $33.33 \%$ think that such elements as dragons and monsters in tales affect children negatively, $33.33 \%$ think that such elements as evil behavior and evil in tales affect children negatively, $26.66 \%$ think that such elements as witches in tales affect children negatively, $26.66 \%$ think that such elements as magic or spell in tales affect children negatively, $21.66 \%$ think that such elements as goblins in tales affect children negatively, $18.33 \%$ think that such elements as fairies in tales affect children negatively, $18.33 \%$ think that such elements as wolves in tales affect children negatively, $16.66 \%$ think that such elements as strict rules in tales affect children negatively, $11.66 \%$ think that such elements as theft in tales affect children negatively, $8.33 \%$ think that such elements as giants in tales affect children negatively, and $1.66 \%$ think that such elements as negative wording in tales affect children negatively. 


\subsection{Findings as regards whether they find the elements in tales contrary to our cultural values inconvenient and why these elements are inconvenient}

Table 6. Frequency and percentage distribution of pre-service teachers concerning whether they find the elements in tales contrary to our cultural values inconvenient and why these elements are inconvenient or not

\begin{tabular}{llcc}
\hline \multicolumn{1}{c}{ Code } & \multicolumn{1}{c}{ Theme } & f & $\mathbf{\%}$ \\
\hline Inconvenient & $\begin{array}{l}\text { As not everyone can learn their culture well } \\
\text { and when children are learning their culture } \\
\text { they suffer from confusions }\end{array}$ & 36 & 60,00 \\
$\begin{array}{l}\text { As the elements taught and experienced do } \\
\text { not coincide } \\
\text { As they are contrary to ethical rules }\end{array}$ & 14 & 23,33 \\
\hline $\begin{array}{l}\text { Not } \\
\text { inconvenient }\end{array}$ & $\begin{array}{l}\text { As they help children know different } \\
\text { cultures }\end{array}$ & 3,33 \\
\hline
\end{tabular}

According to Table 6, 86.66\% of pre-service teachers think that the elements which are contrary to our cultural values in tales are inconvenient, whereas $13.33 \%$ do not think that this is inconvenient. Sixty percent of pre-service teachers claim that they find inconvenience as not everyone can learn their culture properly and that children are suffering from confusions when they learn their culture, $23.33 \%$ think that they find inconvenience as the elements taught and experienced do not coincide, and $3.33 \%$ think that they find inconvenience as they are contrary to ethical rules whereas $8 \%$ think that they do not find inconvenience as they help children know different cultures.

\subsection{Findings concerning the effect of tales on the development of children}

Table 7. Frequency and percentage distribution of pre-service teachers concerning the effect of tales on the development of children

\begin{tabular}{lcc}
\hline \multicolumn{1}{c}{ Theme } & f & $\mathbf{\%}$ \\
\hline $\begin{array}{l}\text { Improves imagination and creativity } \\
\text { Important in terms of cognitive and mental }\end{array}$ & 39 & 65,00 \\
development & 17 & 28,33 \\
It has a didactic effect & 10 & 16,66 \\
Makes contribution to language development & 10 & 16,66 \\
Helps them give direction to their lives & 3 & 5,00 \\
Motivates reading & 3 & 5,00 \\
Ensures empathy development & 3 & 5,00 \\
Provides entertaining leisure time & 2 & 3,33 \\
\hline
\end{tabular}

All teachers stated that tales have positive effects on the development of children. As can be seen in table 7, $65 \%$ of pre-service teachers stated that tales were important as they improved imagination and creativity, $28.33 \%$ of pre-service teachers stated that tales were important as they ensured cognitive and mental development, $16.66 \%$ of pre-service teachers stated that tales were important as they had didactic effect, $16.66 \%$ of pre-service teachers stated that tales were important as they made contribution to language development, $5 \%$ of pre-service teachers stated that tales were important as they helped them give direction to their lives, $5 \%$ of pre-service teachers stated that tales were important as they motivated reading, $5 \%$ of pre-service teachers stated that tales were important as they ensured empathy development, and 3.33\% of pre-service teachers stated that tales were important as they provided entertaining leisure time. 


\subsection{Findings concerning whether tales entail children to extreme imaginary worlds and its reasons}

Table 8. Frequency and percentage distribution of pre-service teachers concerning whether tales entail children to extreme imaginary worlds and its reasons

\begin{tabular}{lllcc}
\hline \multicolumn{2}{c}{ Code } & \multicolumn{1}{c}{ Theme } & f & \% \\
\hline $\begin{array}{l}\text { Yes, it entails to imaginary } \\
\text { world }\end{array}$ & $\begin{array}{l}\text { They try to be like tale characters and } \\
\text { behave like them } \\
\text { They believe in supernatural things }\end{array}$ & 56 & 93,33 \\
$\begin{array}{l}\text { No, it does not entail to } \\
\text { imaginary world }\end{array}$ & $\begin{array}{l}\text { It motivates thinking } \\
\text { It improves imagination }\end{array}$ & 4 & 6,66 \\
\hline
\end{tabular}

An examination of table 8 shows that $93.33 \%$ of pre-service teachers think that tales entail children to extreme imaginary worlds whereas $6.66 \%$ do not agree with this opinion. Pre-service teachers claim that tale tales entail children to imaginary worlds as they try to be like the tale characters and behave like them, and believe in supernatural things. However, according to pre-service teachers who do not agree with this opinion, tales motivate children for thinking and improve their imaginary worlds.

\subsection{Findings concerning what we think positively and negatively about our cultural values in our tales}

Table 9. Frequency and percentage distribution of pre-service teachers concerning what we think positively and negatively about the elements belonging to our cultural values in our tales

\begin{tabular}{llcc}
\hline \multicolumn{1}{c}{ Code } & \multicolumn{1}{c}{ Theme } & $\mathbf{f}$ & $\mathbf{\%}$ \\
\hline Positive opinions & The child becomes aware of the cultural values & 18 & 30,00 \\
& The child knows different cultures & 8 & 13,33 \\
& The child learns cultural elements at an early & 7 & 11,66 \\
& age & \multicolumn{2}{c}{} \\
& The child easily comprehends information & 6 & 10,00 \\
& concerning culture easily & \multicolumn{2}{c}{11} \\
\hline Negative opinions & They do not reflect our culture totally & 26,66 \\
& They are contrary to our cultural elements & 5 & 8,33 \\
& They are not suitable for their age & 5 & 8,33 \\
& They include religious issues & 5 & 8,33 \\
\hline
\end{tabular}

Table 9 shows that $30 \%$ of pre-service teachers see positive aspects in tales as children become aware of their cultural values, $13.33 \%$ think that they know different cultures, $11.66 \%$ think that the child can learn cultural elements at an early age, and $10 \%$ believe that the child can easily comprehend the information given about culture. On the other hand, $26.66 \%$ of pre-service teachers see negative aspects in tales as they do not reflect our culture totally, $8.33 \%$ think that they are contrary to our cultural elements, $8.33 \%$ believe that they are not suitable for the age, and $8.33 \%$ think that they include religious issues.

\section{Discussion, Conclusion and Recommendations}

Although tales seem to be used in order to have fun and entertaining time, everyone knows that tales affect the development of children and that they have educative and didactic aspects. For this reason, it is needed that preschool pre-service teachers have a wide accumulation of knowledge as well as awareness concerning tales. It is observed that there is contradiction between the opinions of pre-service teachers concerning the tales that they will read to children when they become teachers and their opinions on the tales that have the worst negative effects on children. The fact that although pre-service teachers claim that 
some tales can affect children negatively they state that they will teach the same tales shows that they have certain knowledge accumulation but lack awareness. In addition, the fact that they think that some cartoons (Lucky Luke, Batman, Spider-Man etc.) are tales is an indicator of technology and that families cannot prevent this. It is evident that pre-service teachers are under the influence of foreign cultures and, although they are senior students, they have little information about Turkish tales. However, teachers who are supposed to raise next generation should be knowledgeable about tales which reflect our culture in the best manner and read and impose these tales to children. In this way we can choose tales belonging to our culture consciously and make considerable contribution to the development of children. Dilidüzgün believes that consciously choosing a tale to give to a child could eliminate possible inconveniencies [3].

It has been seen that pre-service teachers claimed that when choosing tales they would pay attention to such criteria as being educative and didactic, convenient for the age group of the children, improve imagination, include cultural elements, relate to daily life, make best use of pictures, are written in a clear and understandable language, are entertaining, make contribution to the development of the child and the tale cover is consistent with its content. However, none of the participants mentioned considering the interests and needs of the child. In their study, K1ldan and Bilgici concluded that children's books should be educative and didactic, improve imagination of children and especially address their interests and needs [4].

At the same time, it has been revealed that very few pre-service teachers are aware that cultural elements should be considered while choosing tales.

Pre-service teachers believe that tales which include elements of violence and horror, are unrelated to the reality and contrary to cultural values affect children in a negative direction.

They think that the elements which affect children negatively are violence-warfighting-guns, dragons-monsters, evil behaviors-evil, witches, magic-spell, goblins, fairies, wolves, strict rules, theft, giants and negative wording.

Most of the pre-service teachers think that the elements in tales which are contrary to our cultural values is inconvenient whereas some believe that it is not inconvenient as it would be beneficial if children knew the characteristics of different cultures. Özünel mentioned the relation between tale and culture and stated that each tale reflected the unique viewpoint of the tale that it was told in and continued to include the features of other societies [5].

All pre-service teachers claimed that tales affected the development of children positively. They argued that tales improved imagination and creativity of children, were important in terms of their cognitive and mental development, had didactic impact, contributed to language development, helped them give direction to their lives, motivated reading, and ensured empathy development and having fun leisure time. According to Bilkan, tales improve the imagination of children and are important in terms of the development of native language [6]. Pilanc1 stated that the importance of tales in terms of language teaching, language usage and language awareness could not be disregarded [7]. Several researchers claimed that tales have important function in the education of native languages $[8,9]$.

At the same time, it has been witnessed that several pre-service teachers agree that tales entail children to extremism in terms of imagination.

Pre-service teachers stated that tales are important in that children can become aware of their own cultural values, know different cultures, learn cultural elements in early ages, and easily comprehend the information given concerning culture; they also stated that they had negative opinions about tales which do not fully reflect our culture, are contrary to our 
cultural elements, are not suitable for the age of the child and include religious issues. Feyzioglu claimed that tales were very important in the formation of a cultural identity [10].

As a result, it can be said that most pre-service teachers have a certain accumulation of knowledge about tales but lack the awareness of how to use them. Based on these findings, it is believed that pre-service teachers could benefit from the following recommendations:

- They have to become aware of the fact that tales are important in the education of preschool children,

- They should know that the tales that they will read to the children will affect them either positively or negatively,

- They should consider the interests and needs of children while choosing tales,

- They should primarily prefer the tales which are convenient to our culture and then benefit from the tales in the world literature.

\section{References}

1. TDK, Grand Turkish dictionary, Turkish Language Institute Publications, Ankara, (2015).

2. Meydan larousse, C.8, Meydan Publications, İstanbul, (1972).

3. S. Dilidüzgün, Contemporary children literature, Yap1 Kredi Publications, İstanbul, (1996).

4. A. O. K1ldan, B. G. Bilgici, Determination of opinions of the parents of pre-school children concerning criteria for selecting children books, National Education Journal, 41/192, 105-120 (2011).

5. E. Ö. Özünel, Being a woman at tale place, Geleneksel Publications, Ankara, (2006)

6. A. F. Bilkan, Tale aesthetics, Timaş Publications, İstanbul, (2009)

7. H. Pilanc1, Utilization of folk literature in modern education (Anadolu University Publications, Ankara, (2008).

8. A. T. Görgü, Contribution of tales to the cognitive and emotional development of children. S. Sever (Ed.), II. National Children and Youth Literature Congress Proceedings Book, Ankara University Printing House, Ankara, 537-544 (2007).

9. Z. Gürel, F. Temizyürek, N. K. Şahbaz, Children's literature, Öncü Printing House, Ankara, (2007).

10. Y. Feyzioğlu, Why are tales necessary for children?, S. Sever (Ed.), II. National Children and Youth Literature Congress Proceedings Book, Ankara University Printing House, Ankara, 831-843 (2007). 